\title{
Determinants of Online Religious Service Acceptance: An Empirical Investigation
}

\author{
Jia-Jane Shuai* \\ Department of Information Management, Minghsin University of Science and Technology, Hsinchu, Taiwan. \\ * Corresponding author. Tel.: 886-3-5593142; email: jjshuai@must.edu.tw \\ Manuscript submitted September 6, 2015; accepted December 15, 2015. \\ doi: 10.17706/ijeeee.2016.6.1.21-26
}

\begin{abstract}
The purpose of this research aims to improve the understanding of what motivates individual users to use online religious services, and which factors affect those motivations, based on the theory of the technology acceptance model (TAM). The research examines the reasons for the success of these websites, as well as the reasons why the users accept the new religious media, in light of the cultural and social advantages that affect Internet religious use in Taiwan. The research model was tested by using the Partial Least Squares (PLS) technique. The results show that perceived usefulness is important in developing adoption intention. Religious experience and, computer experience have influences on the adoption intention through the mediating effect of perceived ease of use. The outcome of the research will be useful for online religious service providers and researchers interested in the topic of online religions.
\end{abstract}

Key words: Online religion, technology acceptance model (TAM), partial least squares (PLS).

\section{Introduction}

The rise of the Internet in the 1990s and the evolution of Internet technologies have dramatically changed social and business practices. The Internet has become a necessity of everyday life and for many it has become a necessity of spiritual life as well. Online religion has become an alternative to visiting traditional brick and mortar temples. The Internet has been used as a space where spiritual rituals are conducted and traditional religious beliefs discussed. As Brenda Brasher [1] notes, "One of the best-kept secrets of cyberspace is the surprising amount of religious practice that takes place there". Research results show that more young people seem to come into contact with religion via the Internet than through local religious communities [2]. The Internet is transforming the religious environment, creating new challenges and opportunities [3], [4]. On the other hand, the Internet provides the opportunity for temples to reach a wider audience and create compelling value propositions never before possible.

\section{Background}

In 2005, Campbell [5] suggested a framework for studying religion and Internet technology. Helland [6] proposed a distinction of Internet religious activities: religion online (importing traditional forms of religion online) and online religion (adapting religion to create new forms of networked spiritual interactions). Other research sought to describe how online religious practice interfaces with different cultures [7]-[9]. The study of new media and religion has also gained recognition as unique and important subfield within Internet studies. However the majority of studies published so far focus on Christianity. 
In Taiwan, the number of the registered Internet users has reached to 10.67 million in 2014 out of a total population of 23 million [10]. $t$ is $46.4 \%$ of the total population of Taiwan. According to Internet World Statistics (2014), Taiwan has a high Internet penetration rate (80.8\%). In 2014, 84.81\% of all households had Internet access (up from 54.4\% in 2003), with $84 \%$ of households using broadband connections (up from $38.9 \%$ in 2003). Beyond access, Taiwan also exhibits one of the highest level of engagement with social media, with more than $96 \%$ of its online population visiting a social networking site in March 2015 (MIC, 2015). 71 percent of Internet users in Taiwan were monthly active social media users, logging on to social media services at least once per month. Although we do not have the statistics about the proportion of time that people spend on the Internet for religious purposes, we can expect that for many Taiwanese people, the Internet has become an important part of their spiritual life.

The technology acceptance model (TAM) is one of the most employed model in IT adoption and acceptance research [11], [12]. Derived from the theory of reasoned action (TRA). The model presents two determinants: perceived usefulness and ease of use. Perceived usefulness is the degree to which an individual believes that using a specific application system will increase his or her performance. Ease of use refers to the degree to which the prospective user expects the system to be free of effort. In the present study, perceived usefulness can be constructed as the extent to which a user believes that using online religion enhances his or her spiritual needs.

\section{Research Model and Hypotheses}

The research model (shown in Fig. 1) underlying the current study is based on the theoretical component of the TAM. This study proposes the following hypotheses with regard to the use of online religion in Taiwan.

\subsection{Computer Experience}

Traditional brick and mortar temples usually are the places for elders have interpersonal relationships with other people in the temple. However, with the rapid growth of the Internet, we would like to know who uses online religion services. A person with little prior experience of computer or Internet may be sufficiently inexperienced to elicit surprise and bewilderment upon discovering applications of the technology. At the other end, a person with extensive prior experience is more likely to be a proficient user of online religion to be aware of advanced features. Consequently a person with high levels of prior experience with computer/Internet will perceive online religion activities to be useful and easy to use.

Hypothesis 1. Computer experience has a significant positive effect on perceived usefulness.

Hypothesis 2. Computer experience has a significant positive effect on perceived ease of use.

\subsection{Religious Experience}

Scholars have recognized individuals and communities from various religions increasingly use new media, including websites, social media, and apps for religious purposes [3]. Previous studies have considered the importance of religious experience on consumer behaviors [8]. The present study therefore proposes that.

Hypothesis 3. Religious experience has a significant positive effect on perceived usefulness.

Hypothesis 4. Religious experience has a significant positive effect on perceived ease of use.

\subsection{Perceived Ease of Use}

Perceived ease of use is defined by Davis [13] as "the degree to which a person believes that using a particular system would be free of effort" (p. 320). In the present study, ease of use refers to the extent to which online religion users believes that using CGM for travel planning will be free from effort. Prior research supported the significant effect of perceived ease of use on behavioral intention, either directly or 
indirectly through perceived usefulness.

Hypothesis 5. Perceived ease of use has a significant positive effect on perceived usefulness.

Hypothesis 6. Perceived ease of use has a significant positive effect on usage intention.

\subsection{Perceived Usefulness}

Perceived usefulness is defined by Davis [13] as "the degree to which a person believes that using a particular system would enhance his or her job performance" (p. 320). There is also extensive empirical evidence that supports the significant effect of perceived usefulness on behavioral intention.

Hypothesis 7. Perceived usefulness has a significant positive effect on usage intention.

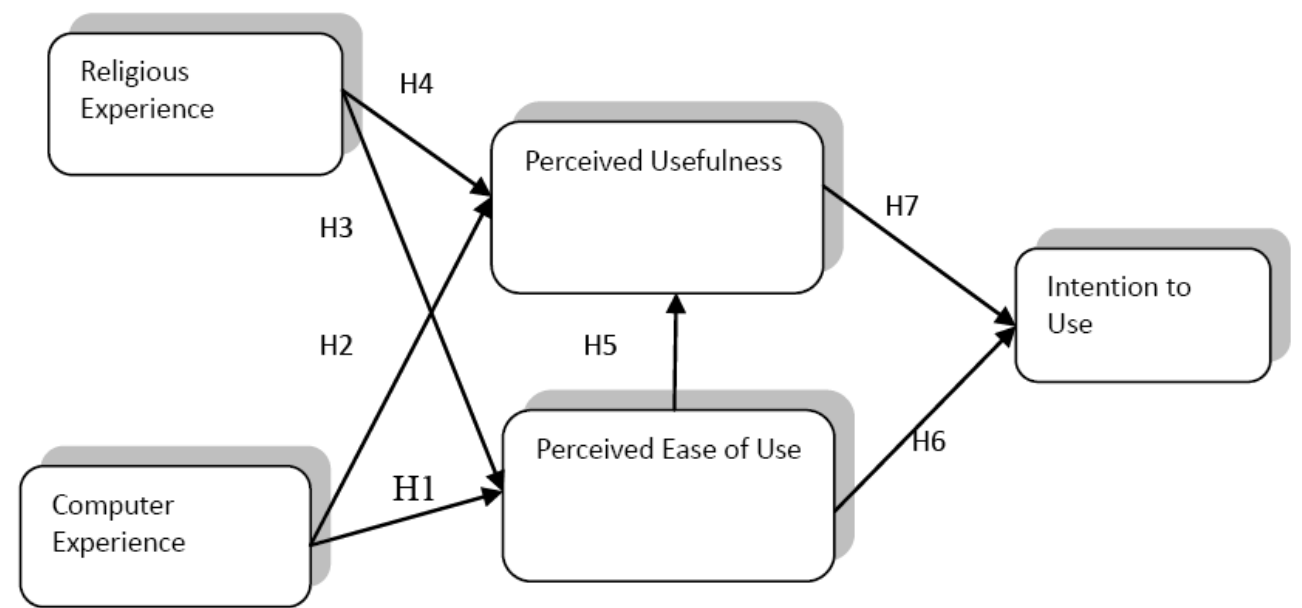

Fig. 1. The research model.

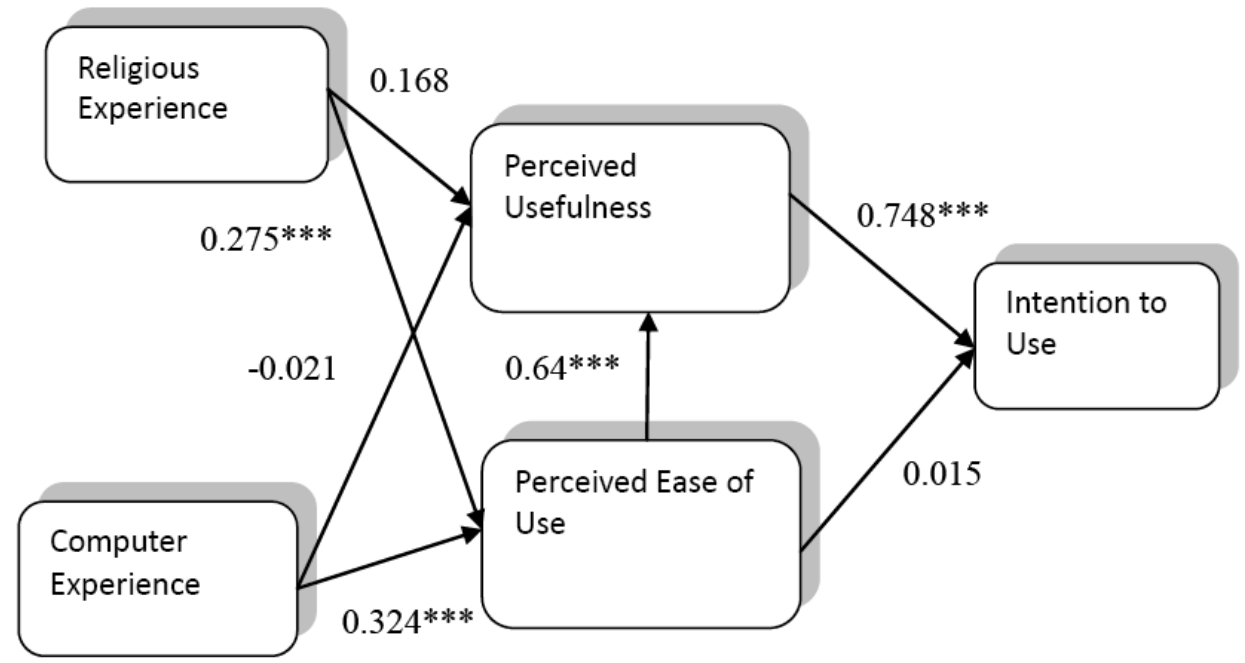

Fig. 2. Results for the research model.

\section{Results}

\subsection{Data Collection Procedures}

Data was collected by two popular religious websites, http://www.8327777.com.tw/service.php and http://www.matsu.org.tw. The test period of the online survey began on February 2012 and ran for two months. A total of 489 people participated in this study. Answers were collected using Google Survey platform. Demographic data for the respondents are presented in Table 1. 
Table 1. Profile of Participants $(N=489)$

\begin{tabular}{|c|c|c|c|}
\hline Profile category & & Frequency & Percentage $(\%)$ \\
\hline \multicolumn{4}{|l|}{ Gender } \\
\hline & Female & 264 & 54.0 \\
\hline & Male & 225 & 46.0 \\
\hline \multicolumn{4}{|l|}{ Age Group } \\
\hline & $<20$ & 40 & 8.2 \\
\hline & $21-30$ & 267 & 54.6 \\
\hline & $31-40$ & 123 & 25.1 \\
\hline & $>41$ & 59 & 12.1 \\
\hline \multicolumn{4}{|l|}{ Education level } \\
\hline & High school/secondary school & 72 & 14.7 \\
\hline & Bachelor degree & 280 & 57.3 \\
\hline & Graduate /Post graduate & 137 & 28.0 \\
\hline \multicolumn{4}{|l|}{ Marital status } \\
\hline & Single & 379 & 77.5 \\
\hline & Married & 110 & 22.5 \\
\hline
\end{tabular}

\subsection{Data Analyses and Results}

Table 2 includes factor loadings, composite reliabilities (CR), average variance extracted (AVE), and Cronbach's alpha.

Table 2. Factor Loadings for Individual Items

\begin{tabular}{|c|c|c|c|c|}
\hline Construct/item & Loading & AVE & $\mathrm{CR}$ & Cronbach's Alpha \\
\hline Computer Experience & & 0.310 & 0.726 & 0.884 \\
\hline Has been using Internet for many years & 0.726 & & & \\
\hline Use Internet more than 10 times a week & 0.841 & & & \\
\hline Use Internet more than ten hours a day & 0.731 & & & \\
\hline Familiar with computer and network & 0.814 & & & \\
\hline Use Internet to find information & 0.806 & & & \\
\hline Willing to use computer for daily life & 0.798 & & & \\
\hline Religious Experience & & 0.457 & 0.798 & 0.726 \\
\hline Visits temple regularly & 0.163 & & & \\
\hline Attends Mazu birthday celebration activities & 0.207 & & & \\
\hline Makes donation to temple regularly & 0.314 & & & \\
\hline Perceived ease of use & & 0.522 & 0.811 & 0.806 \\
\hline Easy to learn how to use & 0.752 & & & \\
\hline Easy to use to find the information needed & 0.773 & & & \\
\hline Easy to use content to worship Ma-Tsu & 0.654 & & & \\
\hline Easy to use content to draw a fortune stick & 0.641 & & & \\
\hline Perceived usefulness & & 0.971 & 0.989 & 0.840 \\
\hline The web site is competent and efficient. & 0.382 & & & \\
\hline The web site makes my religious activities easier & 0.485 & & & \\
\hline The web site makes it easier to get religious information & 0.317 & & & \\
\hline Intention & & 1.150 & 1.020 & 0.920 \\
\hline Plan to add this site to my favorite & 0.516 & & & \\
\hline Plan to recommend this site to friends & 0.566 & & & \\
\hline Intend to continue visiting this website for religious activities & 0.451 & & & \\
\hline
\end{tabular}


To ensure that the constructs were distinct entities, discriminant validity was tested by examining the correlation between constructs as shown in Table 3 .

Table 3. Correlation of Constructs and AVE

\begin{tabular}{llllll}
\hline \hline Construct/item & 1 & 2 & 3 & 4 & 5 \\
\hline 1. Intention & 1.150 & & & & \\
2. Perceived usefulness & 0.744 & 0.971 & & & \\
3. Perceived ease of use & 0.513 & 0.687 & 0.522 & & \\
4. Religious Experience & 0.380 & 0.353 & 0.309 & 0.457 & \\
5. Computer Experience & 0.169 & 0.195 & 0.316 & 0.139 & 0.310 \\
\hline \hline
\end{tabular}

Note: AVE on the diagonal, squared correlations between constructs on off-diagonal

The research hypotheses are tested by assessing the direction, strength and level of significance of the path coefficients estimated by PLS, as shown in Fig. 2. The religious experience and computer experience are predictors of perceived ease of use. Perceived usefulness would significantly affect adoption intention.

\section{Conclusions}

The purpose of our study was to examine factors that determine users' intention to accept online religious services. Although we provided insights to the acceptance of online religion, several limitations exist and they should be addressed in future research. First, participants were all Taiwanese folk religion believers. In order to capture the trend of internet use in religion as a whole, other religions should also be considered in future research. Second, only websites was presented in this study. In future research, it would be beneficial to examine different kinds of media (such as social media, apps).

\section{Acknowledgment}

This study was supported by the ministry of science and technology of Taiwan under contract number 103-2410-H-159 -006-MY2.

\section{References}

[1] Brasher, B. E. (2001). Give me That Online Religion. San Francisco: Jossey-Bass/Wiley.

[2] Lövheim, M. (2008). Rethinking cyberreligion? Teens, religion and the internet in Sweden. Nordicom Review, 29(2), 205-217.

[3] Campbell, H. A., Altenhofen, B., Bellar, W., \& Cho, K. J. (2014). There's a religious app for that! A framework for studying religious mobile applications. Mobile Media and Communication, 2(2), 154-172.

[4] Cheong, P. H., Poon, J. P. H., Huang, S., \& Casas, I. (2009). The internet highway and religious communities: Mapping and contesting spaces in religion-online. Information Society, 25(5), 291-302.

[5] Campbell, H. (2005). Making space for religion in Internet studies. Information Society, 21(5), 309-315.

[6] Helland, C. (2000). Online-religion/religion-online and virtual communitas. In J. K. Hadden, \& D. E. Cowan (Eds.), Religion on the Internet: Research Prospects and Promises (pp. 205-223). New York: JAI Press.

[7] Shuai, J. J., Chen, H. C., \& Chang, C. H. (2010). Visualization of the Taiwanese Buddhism web based on social network analysis. Proceedings of the Computer Symposium (pp. 187-191).

[8] Campbell, H. (2015). Strategic management of religious websites: The case of Israel's orthodox communities. Journal of Computer-Mediated Communication, 20, 467-486.

[9] Kawabata A., \& Tamura T. (2007). Online-religion in Japan: Websites and religious counseling from a comparative cross-cultural perspective. Journal of Computer-Mediated Communication, 12(3), 999-1019. 
[10] Department of Information Services. (2015). Taiwan Yearbook 2014. Government of Information Office, Taiwan.

[11] Lee, Y., Kozar, K. A., \& Larsen, R. T. (2003). The technology acceptance model: Past, present, and the future. Communications of the AIS, 12(3), 752-780.

[12] Legris, P., Ingham, J., \& Collerette, P. (2003). Why do people use information technology? A critical review of the technology acceptance model. Information Management, 40(3), 191-204.

[13] Davis, F. (1989). Perceived usefulness, perceived ease of use, and user acceptance of information technology. MIS Quarterly, 13(3), 319-339.

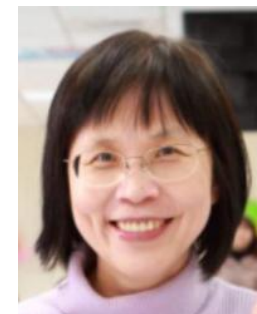

Jiajane Shuai was born in Taiwan in 1964. She got her master degree in computer science from University of Illinois at Urbana-Champion, USA. She received her doctoral degree in information management from National Chiao Tung University, Taiwan. She has been teaching in Ming Hsin University of Science and Technology since March, 1995 and became an associate professor in 2007. Her major research interests are focused on social network analysis and online religions. She also published numerous articles both in Chinese and English in domestic and international academic journals. 